\title{
Intertextual Relationships in Literary Genres
}

\author{
Ayman F. Khafaga ${ }^{1 \& 2}$ \\ ${ }^{1}$ Department of English, College of Science \& Humanities, Prince Sattam bin Abdulaziz University, Saudi Arabia \\ ${ }^{2}$ Department of English, Faculty of Arts \& Humanities, Suez Canal University, Egypt \\ Correspondence: Ayman Farid Khafaga, Department of English Language, College of Science \& Humanities at \\ Al-Aflaj, Prince Sattam bin Abdulaziz University, P.O. Box 710, Al-Aflaj 11912, Saudi Arabia. E-mail: \\ a.khafaga@psau.edu.sa
}

Received: February 10, 2020 Accepted: March 13, 2020 Online Published: March 21, 2020

doi:10.5539/ijel.v10n3p177 URL: https://doi.org/10.5539/ijel.v10n3p177

\begin{abstract}
Most contemporary playwrights acknowledge that Shakespeare's dramas are for use as raw material to be assimilated into contemporary mould, not to be revered strictly as untouchable museum pieces. Being the model of all dramatists, Shakespeare had a great influence on English theatre, his plays are still performed throughout the world, and all kinds of new, experimental work find inspiration in them. This paper investigates the intertextual relationships between William Shakespeare's King Lear (1606) and Edward Bond's Lear (1978). The main objective of the paper is to explore the extent to which Bond manages to use Shakespeare's King Lear as an intertext to convey his contemporary version of Shakespearean classic. Two research questions are tackled here: first, how does Shakespeare's King Lear function as a point of departure for Bond's contemporary version? Second, to what extent does Bond deviate from Shakespeare to prove his originality in Lear? The paper reveals that Bond's manipulation of intertextuality does not mean that he puts his originality aside. He proves his originality by relating the events of the old story to contemporary issues which in turn makes the story keep pace with modern time.
\end{abstract}

Keywords: intertextuality, Shakespeare's King Lear, Bond's Lear, technicalities, thematization

\section{Introduction}

In modern literature, some contemporary playwrights have adapted Shakespearean classics for their own dramatic purposes. The aim beyond this process of Shakespearean influence lies in their desire to show the relevance of Shakespeare's classics to modern time, and to modernize the old ideas of these old works in order to familiarize to contemporary culture. The reason why those playwrights choose Shakespeare's works, in particular, is referred to in Alexander Pope's words that Shakespeare is the only author who deserved the name of an original (cited in Bate, 1970). Shakespeare's singularity is also emphasized by Goethe's argument that Shakespeare left nothing for those to come after him as he exhausted the whole of human nature (cited in Bate, 1970). Further, Bentley wrote that "all roads lead to Shakespeare, or perhaps it might be correct to say that Shakespeare leads to all roads" (cited in Cohn, 1976, p. 389). Thus, Shakespeare's plays have always been a source for contemporary playwrights to acclimatize their themes. Edward Bond is one among the contemporary English dramatists who uses Shakespeare as a catalyst for his plays.

Bond believes that a dramatist concerned with addressing an audience's immediate situation does not always need to deal directly with the present; "the past is also an institution owned by society" (Bond, 1978, p. xiv). Because our present social problems have a history, we can recognize and solve these problems only when we understand this history. Consequently, Bond provides his readers with a series of history plays in which he represents and reinterprets aspects of the historical and cultural heritage in order to create a more usable past, not only this but he considers this activity as one of the artist's primary functions.

As the backbone of English dramatic tradition, Shakespeare is a figure Bond can neither ignore nor whole-heartedly accept. According to Bond, Greek and Shakespearean tragedy continues to provide cultural and artistic standards for contemporary audiences, long after the plays have outlived their social usefulness (Spencer, 1981, p. 127). Bond's Lear is a reworking of Shakespeare's King Lear, a parody of the classical work, and a new version of the old story attempted to be incorporated and assimilated into contemporary mould. The paper, therefore, attempts to show the extent to which Shakespearean original functions as a stimulus and a point of 
departure for Bond's contemporary version. Regardless of the fact that Bond has greatly admired Shakespeare's King Lear, he rewrites the play "to try to make it more relevant" (Wardle, 1970, p. 24). He expresses his own point of view concerning Shakespeare's version in King Lear saying:

I very much object to the worshipping of that play by the academic theatre...because it is a totally dishonest experience. Oh, yes, you know, this marvelous man suffering, and all the rest of it. I think that at the time it would have been a completely different experience to see Lear reacting in the Tudor set up...now, I think it's an invitation to be artistically lazy, to say, "oh, how...sensitive we are and this marvelous artistic experience we're having, understanding this play", and all the rest of it...he's a renaissance figure and he doesn't impinge on our society as much he would. (Wardle, 1970, p. 24)

Bond's rewriting of King Lear does not mean that he objects to Shakespeare's play, but he objects to the ideas that the audiences of King Lear used to understand, for audiences are used to interpret that play as follows: "The human spirit struggles, but it's beaten down, that's how it must be" (Hay \& Roberts, 1980, p. 106). Bond perceives King Lear as a figure that contains elements both worthy of reverence and condemnation. For example, Bond does not accept such renunciation of political responsibility which Shakespeare created on the stage. In his essay Lear as King, Pirie (1980) draws attention to aspects of Shakespeare's drama that seem to have affinities with Bond's approach:

But the play explores more than the mental agony of Lear as a man. It also documents the physical torment to which, as abdicating king, he exposes his subjects... Lear does admittedly discover-however belatedly for a head of state - that society is cruelly unfair to the poor, and that the dispensation of justice by a fallible human being is exceedingly difficult. But he remains incapable of relating these insights either to his own responsibilities as king or to the immediate situation. (pp. 10-11)

Bond acknowledges that he rewrites King Lear not to attack or satirize it but to make its ideas useful for modern audience. Through rewriting King Lear, he wants to present the problems of our modern societies and to offer solutions to these problems. Bond believes that it is difficult to interpret Shakespeare's play in the same way as Shakespeare's audience did. From this context, Bond tries to provide us with a new version of King Lear that can address our contemporary problems. Thus, Bond rewrites Shakespeare's King Lear to offer his readers new dimensions of meanings pertaining to Shakespearean original and relevant to modern times.

Two research questions are tackled here: first, how does Shakespeare's King Lear function as a point of departure for Bond's contemporary version? Second, to what extent does Bond deviate from Shakespeare to prove his originality in Lear? The answer of the two research questions constitutes the main objective of the paper: to explore the extent to which Bond manages to use Shakespeare's King Lear as an intertext to convey his contemporary version.

The rest of this paper is organized as follows: Section 2 offers a general account on the concept of intertextuality, by reviewing some perspectives concerning the literary term, its origin, meaning and principles. Section 3 discusses intertextuality in King Lear and Lear. This section is divided into three subsections: the first subsection presents some intertextual relationships between King Lear and Lear in terms of the dramatic structure; the second subsection clarifies the intertextual relationships between the two plays in terms of characterization; and, the third subsection sheds light on the intertextual relationships between the two plays with respect to thematization. Section 4 discusses the findings of the paper. Section 5 concludes the paper and offers some recommendations for future research.

\section{Intertextuality}

The term intertextuality is derived from the Latin intertexto which means to intermingle while weaving (Childs \& Fowler, 2006). This term is first introduced by the French semiotician Julia Kristeva in the late sixties. The term conveys that any literary work is not simply the product of a single author, but of its relationship with other texts and to the structure of language itself. In her essay word, dialogue, and novel, Kristeva (1980, p. 66) argues that "any text is constructed of a mosaic of quotations; any text is the absorption and transformation of another." Beckson and Ganz (1989, p. 129) explain that the term intertextuality is used to "refer to such matters as influences, sources, allusions, and archetypes in order to suggest how authors echo some elements of other texts in their own works." Eliot expressed a related notion more playfully saying that "minor poets borrow, major poets steal." Such "theft" involves the "intertextual mirror" in which texts reflect each other (cited in Beckson \& Ganz, 1989, p. 129). Further, Culler (1997) in his Literary Theory emphasizes that intertextuality means that any text is a transformation of a previous one and should be understood with regard to its relations to other works. Culler maintains:

Recent theorists have argued that works are made out of other works: made possible by prior books which 
they take up, repeat, challenge, transform. This notion sometimes goes by the fancy name of 'intertextuality'. A work exists between and among other texts, through its relations to them. To read something as literature is to consider it as a linguistic event that has meaning in relation to other discourses. (Culler, 1997, p. 34)

Culler's viewpoint is reinforced by Smyth (1991, p. 14) who considers the postmodern technique of intertextuality as "the greatest liberating feature of postmodern writing." It is also similar to O'Donnell and Con Davis (1989, pp. $\mathrm{ix}-\mathrm{x}$ ) who postulate that "intertextuality regards the text as an ongoing operation....always in process, continually changing its shape." In their view, "a text is a fabric simultaneously being woven and unwoven, made up not of a uniform material... but by the traces of the other." Intertextuality does not mean that a writer or a reader has to be confined to a specific framework of meaning, but it offers a re-reading system that enables the reader to get different meanings from the text. This variety of meanings is governed by the relations of a text to other texts. For Allen (2000), an intertextual reading involves the reader in a network of textual relations, through which one interprets a text or discovers its meaning. Also, Brooker (1999, p. 140) argues that intertextuality implies that "individual texts are inescapably related to other texts and that their meanings are correspondingly provisional and plural according to the way these relations are discerned and highlighted." He also clarifies:

Intertextuality implies, as here, a method of composition but essentially it has determined a way of reading; one which is neither confined to the supposedly immanent of a given text nor seeks this meaning in an external source. Instead, intertextuality promotes a lateral reading across the surface of different interwoven texts. (p. 141)

An intertextual reading of any text entails that the meaning of a text is not a product of a number of words and phrases a text contains. However, it is a result of a variety of writings that are interwoven with each other. "Meaning exists between a text and all the other texts to which it refers and relates, moving out from the independent text into a network of textual relations" (Allen, 2000, p. 1). In this regard, Barthes (1977, p. 146) postulates that "we know that a text is not a line of words releasing a single theological meaning...but a multi-dimensional space in which a variety of writings, none of them original, blend and clash." He maintains that the text is "a tissue of quotations drawn from innumerable centers of culture." For Barthes, intertextuality proclaims the death of the author because he rejects the idea that offers the author a kind of domination over texts. He sees intertextuality as a way of accounting for the role of literary materials without recourse to traditional notions of authorship. Barthes maintains that "once the author is removed, the claim to decipher a text becomes quite futile"; "to give a text an author is to impose a limit on that text," and "to furnish it with a final signified, to close the writing" (ibid., p. 147). Intertextuality, thus, conveys the fact that all literary production takes place in the presence of other texts. Consequently, it is not a matter of authorship that creates a text, but it is the fact of intertextuality that allows the text to come into being, Barthes argues:

Any text is a new tissue of past citations. Bits of codes, formulae, rhythmic models, fragments of social languages, etc., pass into the text and are redistributed within it, for there is always language before and around the text. Intertextuality, the condition of any text whatsoever, cannot, of course, be reduced to a problem of sources or influences; the intertext is a general field of anonymous formulae whose origin can scarcely ever be located; of unconscious or automatic quotations, given without quotation marks. (Barthes, 1981, p. 39)

As Barthes rejects the notion that the author is the person who gives birth to the text, he also attacks the notion of the text as an autonomous and independent entity. For him, intertextuality is the condition of any text. Any text consists of some elements that are presented in other texts, or as he puts it, "any text is an intertext; other texts are presented in it, at varying levels, in more or less recognizable forms: the texts of the previous and surrounding culture" (Barthes, 1981, p. 39). As such, intertextuality implies a re-reading and a re-writing of the previous texts, which in turn indicates that a reader participates in the creation of a text. Thus, one can say that there are two kinds of reading: reading which is merely an act of reading and reading which has an effective role that stimulates the reader's creative potentialities. Barthes $(1981$, p. 42) distinguishes between the two kinds of reading saying that there are readings which are "mere acts of consumption" and "full reading," in which "the reader is nothing less than one who desires to write, to give himself up to an erotic practice of language." The same idea is shared by Atwood (cited in Ingersoll, 1990, p. 178) who believes that reading has an active and creative role and that all readers are different in dealing with texts. She states that readers participate in the creation of texts, which, for her, are "a product of their own labor, not just your labor".

According to Kristeva (1980, p. 37), intertextuality communicates the idea that texts have no stable meaning on their own, but are connected to the ongoing social, cultural and historical processes. A text is always in a state of "production" rather than a "product" to be quickly consumed. In this regard, texts, she argues, are born from a 
process of production that involves both readers and author. This production process can be both constructive and destructive; that is, it can harmonize certain meanings with what is inserted in a text, or to refuse it and, thus, deconstructs it to discover new meanings pertaining to the same text. This idea chimes with the theoretical agenda of critical discourse analysis (CDA) (Fairclough, 1995, 2013 [1989]; van Dijk, 2001, 2014) in the sense that CDA can analytically be perceived to be a deconstructive approach of analyzing language (see Khafaga, 2017a, 2017b, 2019). Furthermore, Barthes (1981) agrees with Kristeva (1980) that the text is created in the meeting of the reader and the work, hence the productive equivalent of writing and reading. He believes that "intertextuality is the general discursive space that makes a text intelligible" (Barthes, 1981, p. 106).

To Eagleton (2008), intertextuality becomes less a name for a work's relation to particular prior texts than a designation of its participation in the discursive space of a culture. The study of intertextuality is not the investigation of sources and influences as traditionally conceived; it casts its net wider to include anonymous discursive practices, codes whose origins are lost, that make possible the signifying practices of later texts. Intertextuality, thus, has a double focus as it calls our attention to the importance of prior texts, insisting that the autonomy of texts is a misleading notion and that a work has the meaning it does only because certain things have previously been written. However, in so far as it focuses on intelligibility, on meaning, intertextuality leads us to consider prior texts as contributions to a code which makes possible the various effects of signification (Haberer, 2007). Now, one can suppose that intertextuality involves a reader to read certain texts and into which he inserts himself by rewriting them. This is completely evident in Bond's Lear, where he uses Shakespeare's King Lear as an intertext to express his own version. Bond borrowed some elements from Shakespeare's original. This process of borrowing sometimes implies a parody of an idea or taking over some words that are already mentioned in Shakespeare's play. Significantly, this process of borrowing is the essence of intertextuality.

\section{Intertextual Relationships Between King Lear and Lear}

It is noteworthy that Bond manipulates intertextuality to retain the basic narrative structure of King Lear: an authoritarian ruler, who loses power, then comes into bloody conflict with his daughters, unleashing a tide of civil and personal violence. However, Bond uses his originality to alter most of the features of Shakespeare's play, and to make the story very much his own. There is, for example, no sub-plot to counterbalance the horror through which Lear passes, no heroic Edgar to lurk in disguise on the heath and turn up at the last minute to vanquish evildoers in mortal combat, nor any loving followers or redemptive daughter to battle for his life; Bond's Cordelia is a more ruthless force altogether. Goneril and Regan become Bodice and Fontanelle. Now, to clarify the way Bond uses King Lear as an intertext in Lear, it is necessary to proceed to more details to show how he deviates from Shakespeare and how he proves his originality in such a dexterous way that makes readers of the play conceive it as really a sole product of his own.

\subsection{Intertextuality and Dramatic Structure: Plot and Characterization}

In King Lear, Shakespeare presents two plots: the main plot and the sub-plot. The two plots tackle the same theme: the ingratitude of sons and daughters. Bond's Lear, on the other hand, has one main plot and there is no sub-plot. Shakespeare's King Lear consists of five acts whereas Bond's Lear consists of three acts. Bond's plot develops through eighteen scenes as opposed to Shakespeare's twenty-six.

The main plot of Shakespeare's King Lear deals with the story of King Lear and his three daughters: Goneril, Regan, and Cordelia. Lear has decided to transfer all his power and authority to his three daughters and to divide his kingdom among them according to their protestation of love. Goneril and Regan make extravagant professions of their love for their father, whereas Cordelia remains silent. As a result, Lear deprives Cordelia of everything. Afterwards, Regan and Goneril treat their father badly and turn him out of doors, while Cordelia marries the King of France and returns with an army to save her father's life. But her army is defeated and she is taken as a prisoner. Lear realizes his rash action but it is too late for Cordelia dies at the end of the play. The sub-plot deals with the story of Gloucester and his two sons: Edgar and Edmund. Edmund is a villain who is similar to Goneril and Regan. Gloucester commits Lear's mistake and drives Edgar out of his home. But at the end he is blinded and in his blindness, he gains more insight, realizes his foolishness and repents.

In Lear, Bond presents a king who has two daughters, Bodice and Fontanelle. This king uses the labor to build a great wall in order to secure his country from any foreign attack and to protect his people from enemies, namely Cornwall and North. His daughters, Bodice and Fontanelle, at first, seem as sensible as their prototypes, Goneril and Regan; for they express their great love and loyalty to their father and at the same time they have an inner intention to marry their father's hereditary enemies, the Duke of Cornwall and the Duke of North. Before long, they have overthrown their father and established a new regime for themselves which is more vicious and violent than his. At last, they are overthrown by a revolutionary army led by Cordelia, the wife of a farmer who has been 
murdered for harboring the fugitive Lear. Bodice and Fontanelle are killed without trial and people are forced to build the selfsame wall. Many of the old atrocities are committed and Lear himself is blinded in an attempt to make him politically ineffective, with what the doctor, performing the operation, calls, "not an instrument of torture, but a scientific device" (Lear: Act 2, Scene 6, p. 63). Lear learns that he must act, so he begins to deliver social parables to pilgrims visiting the Tolstoyan homestead where he lives with his disciples. But the government finds his enthusiasm for disarmament dangerous and prepares to execute him. Lear travels to the wall and is shot as he begins to destroy it.

The first part of Shakespeare's King Lear dramatizes moments of choice: His Lear chooses to abdicate; to reject Cordelia in favor of Regan and Goneril; he dictates the terms of his retirement; he chooses to leave Goneril's house rather than compromise; and, finally, to leave Gloucester's castle and seek the storm. On the contrary, Bond's play reverses this process. His Lear does not choose to surrender power and status, but they are wrested from him. His apparent madness, the suffering which he passes through and his retreat into a nightmarish world of tortured images is a phase through which he reaches a more rational understanding of his situation and thereupon acts morally.

Both Regan and Fontanelle are similar in many respects. They are strong-willed and are pre-occupied by images of power. They are also harshly calculating in their use of others and they are both selfish and passionate. Shakespeare's Cordelia is Lear's beloved daughter, she is dutiful and loving to him, but she is deeply wronged. On the other hand, there is no loving daughter in Bond's Lear. Bond's Cordelia is set outside the royal family. She is a political figure and is introduced as a revolutionary leader. In Shakespeare's King Lear, there are three characters introduced to us to accompany Lear in his desolation: The Fool, Edgar, and Kent, while in Bond's Lear, the character of the Gravedigger's Boy fulfils in part the roles of the Fool and Edgar but he does not survive. He attaches himself to the deposed king and his presence helps to instruct the old man in pity. The previous general assessment of both King Lear and Lear shows that most elements of Shakespeare's play are radically changed and Bond makes the story very much his own. But this does not mean that Lear is a mere product of his originality, the fact is that his Lear is a mixture of originality and intertextuality.

\subsection{Intertextuality and Lexicalization}

Bond uses King Lear as an intertext to write Lear, a play which contains many elements of Shakespeare's original, particularly the first act which is considered a parody of Shakespeare's play; an ironic representation of the myth that governs King Lear. Apparently 'myth' means the ideas men live by. This 'myth' is represented by the map which is discussed in the first scene of Shakespeare's play and which shows King Lear's kingdom as he would like it to be; ironically, what the map depicts never comes to be.

Lear: Meantime, we shall express our darker purpose.

Give me the map there. Know that we have divided

In three our kingdom; and 'tis our fast intent

To shake all cares and business from our age,

Conferring them on younger strengths, while we

Unburthen'd crawl toward death. (King Lear: Act I, Scene I, pp. 5-6)

In Act Two of Lear, Bond echoes the same word 'map' when a soldier says, “we never come straight an' the maps is US". Here 'maps' represent reality even less than they once did, but they still have power which is clearly shown by Bodice when she says, "the map's my straitjacket.... I'm trapped" (Lear: Act 2, Scene 4, pp. 43, 48). Lear's wall is a futile attempt to impose the map of his ideas on the real surface of the earth; he even tries to build it across a swamp. "Both walls and maps represent the futility of trying to impose human conceptions on the natural world; they imply an attack on the orderly values of Shakespeare's play" (Nodelman, 1980, p. 270).

Bond continues to use King Lear as an intertext when he borrows his speech about the suffering of his king from Shakespeare's play. Bond allows his king to say, "I'm old and too weak to climb out of this grave again" (Lear: Act 1, Scene 5, p. 17). Bond's Lear acknowledges that he learns from his suffering, but instead of feeling pity for the suffering of others, he merely demands the peace of death. Shakespeare's king expresses a similar statement when he tells Cordelia, “you do me wrong to take me out o' th' grave" (King Lear: Act IV, Scene VII, p. 190). However, he says it only after he has suffered almost all he will suffer, when his growing consciousness of his own human weakness leads him to pity others. The situations in which both kings utter their words are completely different; Shakespeare's Lear makes his speech about the grave after he experiences too much suffering, whereas Bond's Lear delivers his speech about the same grave before he experiences the horrors of the rest of the play. 
Commenting on this, Nodelman (1980) argues:

Bond implies that Shakespeare's Lear learned much "wisdom" from comparatively little pain, that to believe one has suffered enough is always an act of arrogance, and that in any case, what King Lear learned was not truly wise. What he learned was his obligation to keep the world orderly and prevent suffering. Bond's Lear believed that all along; it was the source of his suffering. So, he acts on the new wisdom he thinks he has learned in the same way he acted on the old wisdom. (p. 271)

Towards the end of Act Two, Bond manipulates intertextuality when he borrows the words 'endure' and 'patience' to express the reaction of his king after he has been blinded. Bond's Lear says, "I could learn to endure my blindness with patience, I could never endure this!" (Lear: Act 2, Scene 7, p. 66). This statement is borrowed from Shakespeare's play because it is similar to the speech of Shakespeare's Lear when he says, "I will be the pattern of all patience" (King Lear: Act III, Scene II, p.108), and "I will endure" (King Lear: Act III, Scene IV, p.114). Here intertextuality lies in the borrowing of the two words 'endure' and 'patience' which signifies to explain the suffering of the speaker. Bond's Lear has come to understand that "wisdom is not a way of preventing pain, but an acceptance of its inevitability" (Nodelman, 1980, p. 274). Now what he cannot endure is that, while his suffering has made him wise, no one else will make his suffering meaningful by learning from his wisdom.

Regardless the fact that Bond uses intertextuality to demonstrate the suffering of his king through the borrowing of the words 'endure' and 'patience,' he fails to create a harmony between his king's words and his actions that follow; that is, there is a contradiction between what Bond's Lear has said and what he has done. Unlike Shakespeare's king who learns from his suffering, Bond's Lear does not learn anything; when, after being helped through madness by the Gravedigger's Boy, he says, "I should have spent my life here" (Lear: Act 1, Scene 7, p. 24), his words sound correct. The Boy knows how to live, and Lear wants to live like the Boy. But Bond shows that his king does not really understand by having him add:

It's so simple and easy here...I could have a new life here. I could forget all the things that frighten me - the years I've wasted, my enemies, my anger, my mistakes. I've been too trusting, too lenient! I'm tormented by regrets-I must forget it all, throw it away! Yes! - let me live here and work for you. (Lear: Act 1, Scene 7, p. 25)

Now, instead of learning how to endure his suffering, Lear forgets all the things that frighten him, and once again he imprisoned himself within a mythical belief that this new life with the Boy will lend him peace and security. Unfortunately, the actions of the play prove that he is wrong. He never learns from his past experiences when he believed that walls can achieve peace and security and he wants to commit the same mistake that instead of committing himself to tear walls down, he wants to build them stronger; he helps the Boy's wife make a wall of sheets in the midst of paradise, and is still trying to keep his enemies out, he tells her, "you go! It's you who're destroying this place! We must get rid of you!" (Lear: Act 1, Scene 7, p. 27). Nodelman (1980) comments on Lear's desire to live with the Boy and to build another wall of sheets by arguing that it is a desire that is built on a false belief that walls achieve security and tranquility. For him (ibid., p. 272), "Lear admires the Boy's life for the wrong reasons; he thinks it will prevent suffering, just as he earlier believed his wall would prevent suffering". Obviously, by means of intertextuality, Bond tries to show the flaws in Shakespeare's myth; having gone through everything Shakespeare's Lear suffered, Bond's Lear learns nothing at all. He fails to understand because he cannot stop wall-building; and despite the bitter experiences he had passed through, he still thinks that right behavior prevents suffering. However, towards the end of Act One, his mythical belief, that the Boy's life will prevent suffering comes to an end, the walls have been breached. The sheets tumble in a sea of blood, as Lear's attempt to build walls around the good life destroys it.

It is noteworthy that the first act in Bond's Lear parallels the end of Shakespeare's play. In scene seven of this Act, Bond recalls the last moments of Shakespeare's Lear by parodying the last words of the king. Lear, holding the body of the dead Cordelia, says, "Look on her, look, her lips/. Look there, look there" (King Lear: Act V, Scene III, p. 218). Similarly, the Boy, near the end of Act One, holds the body of the dying Warrington and says, "My God!- he's breathing. There are bubbles on his mouth! Look! Look!” (Lear: Act 1, Scene 7, p. 29), then for the first time in the play, the Boy speaks his wife's name, Cordelia, which is considered a kind of borrowing from Shakespeare's original since Bond offers her the same name of Shakespeare's heroine. The reason for introducing Cordelia's name in this situation signifies to explain that she is introduced to us towards a behavior that will make her deserve her name. Instead of dying, like Shakespeare's heroine, she comes to life as Lear's real daughter, the person who acts as he once did; horrified by evil, she will work to eradicate it.

\subsection{Intertextuality and Thematization}

Proceeding with the same dexterous use of intertextuality, Bond employs King Lear as an intertext to reverberate 
some ideas presented in Shakespeare's classic. One of these ideas is that of the mock-trial scene which is dramatically introduced in Act Three, Scene Four in King Lear. This trial which Lear imagines is one result of the suffering which he was burdened with. Lear, in a state of madness, imagines that he brings both Goneril and Regan to trial for their crimes. The old king appoints Edgar, Kent, and the Fool to be the judges. He accuses Goneril of kicking the poor king, and accuses Regan of having a very hard heart, not only this but he goes on saying that the body of Regan should be dissected in order to find out why her heart had become so hard. It is the ingratitude of both Regan and Goneril that causes the king's madness and makes him imagine such a trial:

Lear: I'll see their trial first. Bring in their evidence.

(To Edgar.) Thou robed man of Justice, take thy place;

(To the Fool.) And thou, his yoke-fellow of equity,

Bench by his side. (To Kent.) You are

Oth' Commission,

Sit you too.

Arraign her first;' tis Goneril. I here take my oath

Before this honourable assembly, she kicked the poor King her father.

And here's another, whose wraped looks proclaim

What store her heart is made on. Stop her there!

Arms, arms, sword, fire! Corruption in the place!

False justicers, why hast thou let her 'scape? (King Lear: Act III, Scene VI, p. 133:4)

The scene signifies to explain that the ultimate aim of Shakespeare is to demonstrate the suffering of his king. In Lear, Bond echoes the same idea of trial, but here the trial is not organized by the king for his daughters. Conversely, the king himself is really brought for trial before a judge who has been ordered by Bodice to aggravate and condemn Lear:

Bodice: You've studied your instructions?

Judge: Indeed ma'am.

Bodice: This is a political trial: politics is the higher form of justice. The old king's mad and it's dangerous to let him live. Family sentiment doesn't cloud our judgment. I've arranged to call the people who upset him most. I'm a witness.

Fontanelle: Let him rattle on and condemn himself. Goad him if it helps - but not too openly.

Judge: I understand ma'am. (Lear: Act 2, Scene 1, p. 32)

Bond not only manipulates intertextuality to echo the same idea of trial, but also he proves his originality when he deviates from Shakespeare and makes the trial a true fact not an imaginary thing, or a part of hallucination as it is in Shakespeare's original. Bond wants to communicate a different meaning than Shakespeare's play tends to do. While the aim of Shakespeare's trial is to show the amount of suffering and its consequences on his king, Bond's trial aims at emphasizing that family and society are responsible for shaping and/or misshaping their children.

The second act of Bond's Lear further emphasizes the intertextual relationship between Bond's Lear and Shakespeare's original. This Act presents another idea echoed by Bond, namely the idea of the king's dissociation from his daughters. In Shakespeare's play, Lear says to Goneril, "Are you our daughter?", and "I should be false persuaded I had daughter" (King Lear: Act I, Scene IV, P. 48). Similarly, in Bond's Lear, the king proclaims, "I have never seen them.....they are not my daughters!" (Lear: Act 2, Scene 1, p. 33). Bond's parodies Shakespeare's remarks in order to reflect the ingratitude of Lear's daughters. Accordingly, intertextuality is used here to maintain the same theme of ingratitude as expressed by Shakespeare. Bond goes further to borrow the same word 'monster' which is used by Shakespeare to shed light on the cruelty and ingratitude of the daughters. In King Lear, the king says that if ingratitude dominates one's soul, it will appear to be more violent and horrible even than a monster from the sea: 
Lear: Ingratitude, thou marble-hearted fiend,

More hideous, when thou show'st thee in a child,

Than the sea-monster. (King Lear: Act I, Scene IV, p. 50)

In the same manner, and because of the aggravating suffering which emanates from the cruelty of his daughters, Bond's Lear becomes unable to recognize his daughters. The old king says that his daughters have been killed and monsters take their place: "My daughters have been murdered and these monsters have taken their place! I have all their victims cry, where is justice?" (Lear: Act 2, Scene 1, p. 35). Bond's king now asks for justice and he does not know that this justice was murdered when he gave his orders to murder the workers on the wall. Both kings try to dissociate themselves from their daughters; both of them talk about the daughters' ingratitude. However, both of them fail to recognize their responsibility for what their daughters are. Bond's Lear only speaks of their sexuality with disgust and predicts that their selfishness will make them barren:

I know it would come to this! I know you were malicious! I built my wall against you as well as my other enemies! You talk of marriage? You have murdered your family. There will be no more children. Your husbands are impotent...I've watched you scheme and plan...they'll lie by you when you dream! (Lear: Act 1, Scene 1, p. 7)

Among the ideas that Bond reverberates from Shakespeare's King Lear is the idea of anatomization. Here, Bond takes his cue directly from one of Shakespeare's lines. When the original Lear is losing his sanity, the Shakespearean king cries out:

Let them anatomize Regan; see what

Breeds about her heart. Is there any cause in

Nature that make these hard hearts? (King Lear: Act III, Scene VI, p. 135:6)

Bond's echoes this image and then expands it by forcing his Lear to search for the "beast" which inhabits humans' souls, dwells within their bodies and make them so cruel and vicious:

Lear: Is that my daughters...? (points) That's...?

$4^{\text {th }}$ Prisoner: The stomach.

Lear: (Points) that?

$4^{\text {th }}$ Prisoner: The lungs. You can see how she died. The bullet track goes through the lady's lung.

Lear: But where is the...she was cruel and angry and hard...

$4^{\text {th }}$ Prisoner: (points) The womb.

Lear: So much blood and bits and pieces packed in with all that care. Where is the ... where...?

$4^{\text {th }}$ Prisoner: What is the question?

Lear: Where is the beast? The blood is as still as a lake. Where...? Where?

(Lear: Act 2, Scene 6, p. 59)

During the process of search, Bond literalizes Shakespeare's image; Fontanelle is actually anatomized, and as Lear looks at her body, he realizes that he himself damaged what might have been the outer expression of that inner order and beauty:

She sleeps inside like a lion and a lamb and a child. The things are so beautiful. I am astonished. I have never seen anything so beautiful. If I had known she was so beautiful...Her body was made by the hand of a child, so sure and nothing unclean...If I had known this beauty and patience and care, how I would have loved her. (Lear: Act 2, Scene 6, p. 59)

Lear's words here are ironical because they emphasize his ability to respond to Fontanelle's beauty only after she had died.

The theme of blindness is another idea echoed in Bond's Lear. The blinding of Gloucester in King Lear is transferred and matched by the removal of Lear's eyes, through with the same metaphorical effect to Lear himself. Bond "redoubles the horror of the blinding of Gloucester by giving it a touch of clinical expertise which brings to mind the scientific atrocities of the concentration camps and subsequent technological advances in torture" (Salgado, 1980, p. 208). Significantly, the theme of blindness continues the use of Shakespeare's text for Bond's own purposes. As in Shakespeare's play, it is a dramatic metaphor for insight; "I stumbled when I saw" (King Lear: Act IV, Scene I, p. 148) says the blinded Gloucester. The idea that "Lear is blinded immediately after the revelation 
he experiences at the autopsy suggests how much that he has needed to learn he has now learnt" (Smith, 1979, p. 81). The idea of blindness in Bond's Lear also communicates the deliberate and very effective use of anachronisms - the mixing of contemporary and historic detail —in the play. Bond, in a postcard to Gaskill during the rehearsals of the production, spoke of the need to preserve this mixture: "The anachronisms are for the horrible moments in a dream when you know it's a dream but can't help being afraid. The anachronisms must increase, and not lessen the seriousness.... They are like desperate facts" (cited in Dark, 1972, p. 22). Commenting on this process of mixing the contemporary and the historic detail which Bond's Lear presents, Smith (1979) postulates:

This latest scientific gadget which hygienically "decants" the eyes into a "soothing solution of formaldehyde crystals" and sprays the sockets with an aerosol reminds us of modern torture techniques and pseudo-scientific concentration camp experiments practiced on victims of the Nazi terror. (pp. 81-82)

Furthermore, intertextuality is employed to demonstrate a part of the relationship between Lear and the Gravedigger's Boy who represents Shakespeare's Fool. In both King Lear and Lear, the Fool and the Gravedigger's Boy keep the company of the old king; teach him how to feel pity for other people, how to feel the sufferings of the poor and the needy, and how to sympathize with them. In King Lear, the king speaks to the Fool saying:

Lear: Poor Fool and knave. I have one part in my heart

That's sorry yet for thee. (King Lear: Act III, Scene ii, p. 111)

Lear: In boy, go first. Your houseless poverty

Nay get thee in. I'll pray and then I'll sleep. (King Lear: Act III, Scene IV, p. 115)

In Lear, Bond echoes Shakespeare's words to offer his king a feeling of sympathy towards others:

Ghost: Let me stay with you Lear.... Look at my hands they are like an old man's. They're withered, I am young but my stomach's shriveled up, and the hairs turned white. Look, my arms! Feel how thin I am. Are you afraid to touch me?

Lear: Yes, yes, poor boy. Lie down by me. Here, I'll hold you. We'll help each other. Cry while I sleep, and I'll cry and watch you while you sleep. We'll take turns. The sound of the human voice will comfort us. (Lear: Act 2, Scene 2, p. 42)

It is clear from the above quote that there are echoes of Shakespeare's Lear and the Fool on the heath. Also, the Ghost's remarks are a stimulus that makes Lear acknowledge his responsibility for what he has done against others. Now, Lear forgets his own problem and cares for the problems of others as he feels sorry for the harm he has caused to hundreds of people: "And to tell you the truth, I did him a great wrong once, a very great wrong. He's never blamed me. I must be kind to him now" (Lear: Act 2, Scene 5, p. 54). Smith (1979) sees that the care which Lear shows towards the Ghost of the Gravedigger's Boy indicates that the king has an inherent desire to escape from the situation in which he finds himself as deposing king; the king, in relieving the Ghost's suffering, is relieving his own too. Smith (1979, p. 79) maintains that "Lear's human concern for the boy in the Bond scene is moving; but there is also a sense that Lear, in embracing the Ghost, is nursing his own grief too much, and withdrawing into an unreal world".

\section{Findings and Discussion}

The above analysis of the intertextual relationships between Shakespeare's King Lear and Bond's Lear demonstrates a number of findings as follows:

First, Shakespeare's singularity surpasses all who attempt to rewrite his plays or adopt their themes. However, Bond believes that such plays have outlived their historical relevance and hence entered the realm of myth. He, therefore, argues that theatre must commit itself to the task of eliminating this false mythology by analyzing history and reinterpreting literary texts through rewriting these old literary works. The aim beyond rewriting these texts is to make them relevant to modern time.

Second, in Lear, Bond starts from the premise that Shakespeare's plays are truly ours, and not primarily historical. Bond's Lear reflects both a profound admiration for King Lear and an insistence upon the use of the Lear story in a way that makes it intelligible to and a parable for our own times. There are obvious features of Shakespeare's play which are used in Bond's play. Both show a king and a father acting arbitrarily and being opposed by two daughters whose sole concern is to acquire power. Both Lears move from autocratic behavior into a kind of insanity and come towards some understanding and pity. Incidents to do with the partition of the kingdom, blindness, the imprisonment of father and daughter, and the general deployment of animal imagery are common to each of the versions. 
Third, Bond's Lear is a reworking of Shakespeare's King Lear. The play is not totally a product of Bond's originality but a mixture of both originality and intertextuality. This technical device implies that any text is an echo of other texts. Through intertextuality Bond manages to, first, retain the basic narrative structure of King Lear: an authoritarian ruler who loses power, then comes into bloody conflict with his daughters, unleashing a tide of civil and personal violence; second, to keep the names of some characters like Lear and Cordelia; third, to keep the roles of some characters like those of the two daughters who are presented by their prototypes: Bodice and Fontanelle, and the Fool whose role is played by the Gravedigger's Boy; and, fourth, to keep the themes of ingratitude and blindness.

Fourth, Bond uses King Lear as an intertext to express his own version by virtue of borrowing some elements from Shakespeare's original. This process of borrowing sometimes implies a parody of an idea or taking over some words that are already mentioned in Shakespeare's play. The first act of Bond's Lear is considered a parody of Shakespeare's King Lear. Bond also uses intertextuality to demonstrate the suffering of his king through the borrowing of the words 'endure' and 'patience', but he fails to create any kind of harmony between the king's words and his actions because there is a contradiction between what his Lear has said and what he has done.

Fifth, Bond's manipulation of intertextuality does not mean that he puts his originality aside. The fact is that he proves his originality in the sense that he relates the incidents of the old story to contemporary issues which, in turn, makes the story keep pace with modern time. Such originality can be touched in the situation which he echoes from Shakespeare's original. For example, his keeping of the idea of anatomization is to prove that human existence is nothing but an act of violence. His presentation to the theme of blindness is to show that modern technology plays a part in shaping a violent society, and that violence is a product of a dehumanizing social structure. The parody of the daughters' trial is to emphasize that family and society are responsible for shaping or misshaping their children. Thus, intertextuality and originality go side by side in rewriting King Lear.

Sixth, in order to prove his originality, Bond makes radical changes in Shakespeare's original, and he manages to make the story very much his own. For example, there is no sub-plot in Lear to counterbalance the horror through which Lear passes, no heroic Edgar to lurk in disguise on the heath and turn up at the last minute to vanquish evildoers in mortal combat, nor any loving followers or redemptive daughter to battle for his life; Shakespeare's Goneril and Regan become Bodice and Fontanelle.

Seventh, Bond's play differs from Shakespeare's in certain important respects. Shakespeare's Lear draws the lines of his fate from the very beginning by his rash decision to divide his kingdom among his two daughters and to deprive Cordelia, his younger and most beloved daughter, because of her 'nothing'. Bond's Lear, on the other hand, does not think about dividing his kingdom among his daughters, but he is a king who spends his life building a great wall to protect his people from his enemies. Unlike Shakespeare's Lear whose rashness leads to his suffering, Bond's Lear draws the lines of his downfall by his way of bringing up his daughters. They are brought up to fear, not to love.

Eighth, Shakespeare's Lear has to face the fury of the elements without any shelter, while Bond's Lear is given shelter out of pity by the Gravedigger's Boy. Shakespeare's Lear gains insight through suffering. He discovers that law and justice are for the privileged classes and not for the poor common people. Bond's Lear, on the other hand, comes to realize his mistakes through suffering. This realization makes him see better and behave in a different way.

Finally, the final act of Shakespeare's Lear emphasizes his helplessness. He dies unable to do something, whereas the final act of Bond's Lear has its effect on people especially those who symbolize future generations like Thomas and Susan who may be able to change the situation. He dies attempting to destroy the wall, his gesture is heroic but it is also tragic for it costs his life. The death of Bond's Lear looks backwards to the mistakes he must expiate, but also forward to the possibility of a more rational society that may be established by succeeding generations understanding the event. So, the end of Lear's suggests that direct action is imperative and shows that it is very difficult to make any change in an unjust society, but it is not impossible.

\section{Conclusion}

This paper presented a discussion of the intertextual relationships between Shakespeare's King Lear and Bond's Lear. The analysis showed that Bond's Lear is a product of both intertextuality and originality. Although Bond's Lear contains many elements of Shakespeare's original, one cannot ignore Bond's originality in the process of rewriting the old story. His originality lies in his dramatic ability to relate the incidents of the old story to contemporary issues which, in turn, makes the story in conformity with contemporary audience.

The analysis also demonstrated that through intertextuality, Bond manages to retain the basic narrative structure of 
King Lear, to keep the names of some characters like Lear and Cordelia, to keep the roles of some characters like those of the two daughters and the Fool, and to keep the themes of ingratitude and blindness. However, Bond's originality cannot be ignored; it is clearly shown even in the situations that have intertextual relationships with Shakespeare's original. For example, his keeping of the idea of anatomization is to prove that human existence is nothing but an act of violence. His presentation to the theme of blindness is to show that modern technology plays a part in creating a violent society and that violence is a product of a dehumanizing social structure. His parody of the daughter's trial is to emphasize that family and society are responsible for shaping and/or misshaping their children. These ideas indicate that intertextuality and originality go in a parallel direction in the process of rewriting King Lear.

For future research, this paper recommends further studies of the intertextual relationships in other literary genres. This could reveal other findings that emphasize the assumption that many literary texts, be they conversational, narrative or otherwise, however produced in different periods of time and by different authors, are still contingent on each other.

\section{Acknowledgements}

This publication was supported by the Deanship of Scientific Research at Prince Sattam bin Abdulaziz University, Alkharj, Saudi Arabia.

\section{References}

Allan, G. (2000). Intertextuality: The new critical idiom. London: Routledge. https://doi.org/10.4324/9780203131039

Barthes, R. (1977). The death of the author. In Image-music -text (Tran. Stephen Heath). London: Fontana.

Barthes, R. (1981). Theory of the text. In R. Paul (Ed.), Untying the text: A post-structuralist reader. London: Routledge and Kegan Paul.

Bate, J. W. (1970). The burden of the past and the English poet. Harvest University Press. https://doi.org/10.4159/harvard.9780674281011

Beckson, K., \& Ganz, A. (1989). Literary terms: A dictionary (3rd ed.). New York: Farrar, Straus and Giroux.

Bond, E. (1978a). Lear (In Plays two). London: Eyre Methuen.

Bond, E. (1978b). Preface to The Bundle. London: Eyre Methuen.

Brooker, P. (1999). Cultural theory: A glossary. London: Eyre Methuen.

Childs, P., \& Fowler, R. (2006). The Routledge dictionary of literary terms. USA.: Routledge. https://doi.org/10.4324/9780203462911

Cohn, R. (1976). Modern Shakespeare offshoots. New Jersy: Princeton University Press.

Culler, J. (1997). Literary theory. New York: Oxford University Press.

Dark, G. (1972). Edward Bond's Lear at the royal court. Theatre Quarterly, 2(Jan-March).

Eagleton, T. (2008). Literary theory: An introduction. Minneapolis: University of Minnesota Press.

Fairclough, N. (1995). Critical discourse analysis: The critical study of language. London \& New York: Longman.

Fairclough, N. (2013[1989]). Language and power (2nd ed.). London \& New York: Longman. https://doi.org/10.4324/9781315838250

Haberer, A. (2007). Intertextuality in theory and practice. Literatura, 49(5), 54-67. https://doi.org/10.15388/Litera.2007.5.7934

Hay, M., \& Roberts, P. (1980). Bond: A study of his plays. London: Eyre Methuen.

Ingersoll, E. G. (ed.) (1990). Margaret Atwood: Conversation. Princeton, N J: Ontario Review Press.

Khafaga, A. (2017a). Discourse interpretation: A deconstructive reader-oriented approach to critical discourse analysis. International Journal of Applied Linguistics \& English Literature, 6(2), 138-146. https://doi.org/10.7575/aiac.ijalel.v.6n.2p.138

Khafaga, A. (2017b). Linguistic manipulation of political myth in Margaret Atwood's The Handmaid's Tale. International Journal of English Linguistics, 7(3), 189-200. https://doi.org/10.5539/ijel.v7n3p189

Khafaga, A. (2019). Linguistic Representation of Power in Edward Bond's Lear: A Lexico-Pragmatic Approach 
to Critical Discourse Analysis. International Journal of English Linguistics, 9(6), 404-420. https://doi.org/10.5539/ijel.v9n6p404

Kristeva, J. (1980). Word, dialogue, and novel. In S. R. Leon (Eds.), Desire in language: A semiotic approach to literature and art (Trans. Thomas Gora, et al.). New York: Columbia University Press.

Nodelman, P. (1980). Beyond politics in Bond's Lear. Modern Drama, xxlll(3), 269-276. https://doi.org/10.3138/md.23.3.269

O’Donnell, P., \& Robert, C. D. (Eds.) (1989). Intertextuality and contemporary fiction. Baltimore and London: Johns Hopkins University Press.

Pirie, D. (1980). Lear as King. Critical Quarterly, 22(2), 5-19. https://doi.org/10.1111/j.1467-8705.1980.tb01758.x

Salgado, G. (1980). English drama: A critical introduction. London: Edward Arnold Ltd.

Shakespeare, W. (1952). King Lear (The Arden Shakespeare Paperbacks) (K. Muir Ed.). London: Methuen \& Co. Ltd.

Smith, L. (1979). Edward Bond's Lear. Comparative Drama, 13(1), 65-85. https://doi.org/10.1353/cdr.1979.0005

Smyth, E. J. (Ed.) (1991). Postmodernism and contemporary fiction. London: B. J. Batsford Ltd.

Spencer, S. J. (1981). Edward Bond's dramatic strategies. In C. W. E. Bigsby (Ed.), Contemporary English drama (Vol. 19). Stratford-Upon- Avon Studies.

van Dijk, T. A. (2001). Critical discourse analysis. In D. Schiffrin, D. Tannan \& H. Hamilton (Eds.), The handbook of discourse analysis (pp. 352-392). Blackwell.

van Dijk, T. A. (2014). Discourse and knowledge: A socio-cognitive approach. Cambridge: Cambridge University Press. https://doi.org/10.1017/CBO9781107775404

Wardle, I. (1970). A discussion with Edward Bond. Gambit, 5(17), 5-37.

\section{Copyrights}

Copyright for this article is retained by the author, with first publication rights granted to the journal.

This is an open-access article distributed under the terms and conditions of the Creative Commons Attribution license (http://creativecommons.org/licenses/by/4.0/). 